\title{
DETECTION OF CRYPTOSPORIDIUM SPP. IN CALVES THROUGH NESTED PCR AND KINYOUN'S ACID-FAST METHODS IN VAN, TURKEY
}

\author{
Adnan Ayan ${ }^{1 *}$, Ozlem Orunc Kilinc ${ }^{2}$, Nazmi Yuksek ${ }^{3}$, Yildiray Basbugan ${ }^{3}$ \\ ${ }^{I}$ Department of Genetics, Faculty of Veterinary Medicine, Van Yuzuncu Yil University, Van, Turkey; \\ ${ }^{2}$ Özalp Vocational School, Van Yuzuncu Yil University, Van, Turkey; \\ ${ }^{3}$ Department of Internal Medicine, Faculty of Veterinary Medicine, Van Yuzuncu Yil University, Van, Turkey; \\ *Corresponding Author Adnan AYAN, e-mail: adnanayan@yyu.edu.tr;
}

Received January 2020; Accepted February 2020; Published March 2020;

DOI: https://doi.org/10.31407/ijees10.205

\begin{abstract}
Cryptosporidium is a protozoon of zoonotic importance causing infections with diarrhoea and other clinical symptoms in man, domestic, and wild animals. The present study was conducted to determine the prevalence of cryptosporidiosis in diarrhoeic calves which were up to 1 month old in Van, Turkey, using Kinyoun's acid-fast and Nested PCR methods. In this study A total of 164 diarrhoeic calves faecal samples were collected from diarrheic calves at different farms located in Van, Turkey during January 2019 to September 2019. The faecal samples stained with Kinyoun's acid-fast method then examined with microscope. DNAs were extracted from all the faecal samples using RTA stool DNA isolation kit. In order to amplify the SSU rRNA gene region of the DNAs, appropriate primers were used in the Nested PCR. According to the results, In the microscopic examination, Cryptosporidium spp. oocyst were identified in 61 out of 164 diarrhoeic calves faecal samples (37.19\%). Cryptosporidium spp. specific bands of 826-864 bp in size were obtained from 72 out of 164 diarrhoeic calves faecal samples (43.9\%). To the best of our knowledge, no other previous study is available with concern to molecular investigation of the prevalence of Cryptosporidium in calves around Van, Turkey. With this study, it was revealed that cryptosporidiosis is an important agent in calf diarrhoea, and measures should be taken in this regard.
\end{abstract}

Keywords: Cryptosporidium spp., Nested PCR, Turkey 